This PDF is a selection from an out-of-print volume from the National Bureau of Economic Research

Volume Title: Human Capital: A Theoretical and Empirical Analysis with Special Reference to Education (3rd Edition)

Volume Author/Editor: Gary S. Becker

Volume Publisher: The University of Chicago Press

Volume ISBN: 0-226-04119-0

Volume URL: http://www.nber.org/books/beck94-1

Conference Date: $\mathrm{n} / \mathrm{a}$

Publication Date: January 1994

Chapter Title: Human Capital and the Rise and Fall of Families

Chapter Author: Gary S. Becker, Nigel Tomes

Chapter URL: http://www.nber.org/chapters/c11237

Chapter pages in book: (p. 257 - 298) 


\section{Human Capital and the Rise and Fall of Families ${ }^{1}$}

Gary S. Becker and Nigel Tomes

\section{Introduction}

Ever since Pareto discovered that the distribution of larger incomes and wealth is reasonably well approximated by a particular skewed distribution, since then called the "Pareto distribution," economists have continued to discuss inequality in the distribution of earnings, income, and wealth among individuals and families. However, they have paid little attention to the inequality within families over generations as determined by the relation between the incomes or wealth of parents, children, and later descendants. Schumpeter is the only major economist who systematically considered intergenerational mobility with empirical evidence as well as with theoretical analysis (see Schumpeter 1951).

Sociologists and other social scientists, on the other hand, have pre-

'Our research has been supported by National Science Foundation Grant no. SES 8208260 . We received valuable assistance from Gale Mosteller and Michael Gibbs. We appreciate the useful comments at the Conference on the Family and the Distribution of Economic Rewards and at seminars at Bar-Ilan University, Brigham Young University, the University of Chicago, the Hebrew University, Institute des Etudes Politiques, the University of Pennsylvania, Purdue University, Stanford University, and the University of Western Ontario. We especially thank Robert Willis for his helpful discussion at the Conference on the Family and the Distribution of Economic Rewards. We have also benefited from suggestions by Arthur Goldberger and Sherwin Rosen. 
sented considerable empirical evidence on the occupations, education, and other characteristics of children and parents. Blau and Duncan (1967), in the influential book The American Occupational Structure, consider the effect of family background on the achievements of children. As long ago as 1889 , John Dewey wrote, "[U]pon the average, children of parents who are exceptional, or who deviate from the mean, will themselves deviate from the mean only one third of their parents' deviation.... It is not likely that children of the poor would be better off, and children of the wealthier poorer in anything like the ratio of $2 / 3^{n}$ (Dewey [1889, pp. 333-34]; this statement was brought to our attention by $O$. D. Duncan).

Although discussions of inequality among families have been almost entirely separate from discussions of inequality between generations of the same family, these inequalities are analytically closely related. In particular, regression away from the mean in the relation between, say, the incomes of parents and children implies large and growing inequality of income over time, while regression toward the mean implies a smaller and more stable degree of inequality. These statements are obvious in a simple Markov model of the relation between parents and children:

$$
I_{i+1}=a+b I_{i}+\varepsilon_{t+1}
$$

where $I$, is the income of parents, $I_{i+1}$ is the income of children, $a$ and $b$ are constants, and the stochastic forces affecting the income of children $\left(\varepsilon_{t+1}\right)$ are assumed to be independent of the income of parents.

Inequality in income will continue to grow over time if $b$ is greater than or equal to unity, while inequality in income will approach a constant level if $b$ is smaller than unity in absolute value. Clearly, the size of $b$ also measures whether children of richer parents tend to be less rich than their parents and whether children of poorer parents tend to be better off than their parents. This example implies that, even in rigid and caste-dominated societies, many of the elite and underprivileged families would change places over generations unless inequality continued to grow over time $(b \geq \mathrm{I})$.

The degree of regression toward or away from the mean in the achievements of children compared to those of their parents is a measure of the degree of equality of opportunity in a society. The purpose of this paper is to analyze the determinants of unequal opportunities, sometimes called "intergenerational mobility," or, as in the title of our paper, "the rise and fall of families." We use all these terms interchangeably.

The many empirical studies of mobility by sociologists have lacked a 
framework or model to interpret their findings. We try to remedy this defect and to fill a more general lacuna in the literature by developing a systematic model that relies on tutility-maximizing behavior by all participants, equilibrium in different markets, and stochastic forces with unequal incidence among participants.

An analysis that is adequate to cope with the many aspects of the rise and fall of families must incorporate concern by parents for children as expressed in altruism toward children, investments in the human capital of children, assortative mating in marriage markets, the demand for children, the treatment by parents of exceptionally able or handicapped children, and expectations about events in the next or in even later generations. Although these and other aspects of behavior are incorporated into a consistent framework based on maximizing behavior, we do not pretend to handle them all in a satisfactory manner. However, our approach indicates how a more complete analysis can be developed in the future.

The next section has a lengthy discussion of investments in the human capital of children. The discussion is lengthy because the relation between the earnings of parents and children is the major determinant of the rise and fall of most families. Section 3 moves on to consider the interaction between investments in human capital, transfers of material wealth (gifts and bequests) from parents to children, and the evolution of consumption over generations.

Section 4 considers the effect of the number of children on intergenerational mobility of consumption and wealth and also the effect on mobility of assortative mating in marriage markets.

Section 5 assembles about a dozen studies of the degree of regression to the mean between parents and children in income, earnings, and wealth. Available studies are few and are based on limited data, but the magnitudes of some basic parameters of our model are suggested by the evidence for the United States and other countries.

Much of our analysis of human capital is based on the model developed in Becker's Woytinsky Lecture (1967) to explain different investments among families. However, that lecture is mainly concerned with inequality and skewness in earnings and wealth and does not derive relations between the earnings and assets of parents and children. The approach in this paper is also based on a series of papers by us in the last decade that analyzes marriage, fertility, altruism of parents, and longrun equilibrium relations between parents and children (see esp. Becker 1974, 1981; Becker and Tomes 1976, 1979; Tomes 1981).

The present paper is closest in spirit to Becker and Tomes (1979), but these papers differ in important ways. We believe that the present 
discussion is a considerable improvement. We now distinguish human capital and earnings from other wealth, and we incorporate restrictions on the intergenerational transfer of debt. We assume now that parents' utility depends on the utility of children instead of on the permanent income of children. We also consider the effect of endogenous fertility on the relation between the wealth and consumption of parents and children. These improvements explain why the implications of the present paper are sometimes quite different from those of the earlier paper. In an essay devoted to critiquing parts of Becker (1981), Becker and Tomes (1984), and an earlier draft of this paper, Goldberger (1985) sometimes fails to see these differences between the current paper and our earlier work. We comment further on his critique elsewhere in this paper.

Since inequality over generations and inequality between families are closely related (as implied by eq. [1]), any adequate analysis of inequality must also consider marital patterns, fertility, expectations about future generations, and investments in human capital. Therefore, it is hardly surprising that a growing literature during the last 15 years has tried to integrate more realistic models of family behavior into models of the distribution of income and wealth. ${ }^{2}$ Although this literature and our work have many similarities, the present paper is almost alone in relating the rise and fall of families to investments in human capital that interact with the accumulation of assets, the evolution of consumption, and the demand for children.

\section{Earnings and Human Capital}

\section{Perfect Capital Markets}

Some children have an advantage because they are born into families with greater ability, greater emphasis on childhood learning, and other favorable cultural and genetic attributes. Both biology and culture are transmitted from parents to children, one encoded in DNA and the other in a family's culture. Much less is known about the transmission of cultural attributes than of biological ones, and even less is known about the relative contributions of biology and culture to the distinctive endowment of each family. We do not need to separate cultural from ge-

\footnotetext{
"Among the important contributors to this literature are Stiglitz (1969), Blinder (1974), Conlisk (1974), Behrman and Taubman (1976), Meade (1976), Bevan (1979), Laitner (1979), Menchik (1979), Shorrocks (1979), Loury (1981), and Atkinson (1983).
} 
netic endowments, and we will not try to specify the exact mechanism of cultural transmission. We follow our previous paper (Becker and Tomes 1979; see also, e.g., Bevan 1979) in assuming as a first approximation that both are transmitted by a stochastic-linear or Markov equation:

$$
E_{t}^{i}=\alpha_{t}+h E_{t-1}^{i}+v_{t}^{i}
$$

where $E_{i}^{i}$ is the endowment (or vector of endowments) of the $i$ th family in the th generation, $h$ is the degree (or vector of degrees) of "inheritability" of these endowments, and $v_{\ell}^{\prime}$ measures unsystematic components or luck in the transmission process. We assume that parents cannot invest in their children's endowment.

A priori restrictions on the magnitude or even on the sign of the inheritability of endowments are unnecessary since the degree of inheritability can be estimated from accurate information on the earnings of parents and children (and perhaps also grandparents). Yet the assumption that endowments are only partially inherited, that $h$ is less than unity and greater than zero, is a plausible generalization to cultural endowments of what is known about the inheritance of genetic traits. This assumption implies that endowments regress to the mean: children with well-endowed parents tend also to have above-average endowments but smaller relative to the mean than their parents', whereas children with poorly endowed parents tend also to have below-average endowments but larger relative to the mean than their parents'.

The term $\alpha_{t}$ can be interpreted as the social endowment common to all members of a given cohort in the same society. If the social endowment were constant over time, and if $h<1$, the average endowment would eventually equal $1 /(1-h)$ times the social endowment (i.e., lim $\left.\bar{E}_{t}=\alpha /[1-h]\right)$. However, $\alpha$ may not be constant because, for example, governments invest in the social endowment.

Practically all formal models of the distribution of income that consider wages and abilities assume that abilities automatically translate into earnings, mediated sometimes by demands for different kinds of abilities (see, e.g., Roy 1950; Mandelbrot 1962; Tinbergen 1970; Bevan and Stiglitz 1979). This is useful in understanding certain gross features of the distribution of earnings, such as its skewness, but is hardly satisfactory for analyzing the effect of parents on their children's earnings. Parents not only pass on some of their endowments to children, but they also influence the adult earnings of their children by expenditures on their skills, health, learning, motivation, "credentials," and many other characteristics. These expenditures are determined not only by the abilities of children but also by the incomes, preferences, and fertility of par- 
ents as well as the public expenditures on education and other human capital of children and other variables. Since earnings are practically the sole income for most persons, parents influence the economic welfare of their children primarily by influencing their potential earnings.

To analyze these influences in a simple way, assume two periods of life, childhood and adulthood, and that adult earnings depend on human capital $(H)$, partly perhaps as a measure of credentials, and market luck $(\ell)$ :

$$
Y_{i}=\gamma\left(T_{i} f_{t}\right) H_{i} \alpha+\ell_{t}
$$

The earnings of one unit of human capital $(\gamma)$ is determined by equilibrium in factor markets. It depends positively on technological knowledge $(T)$ and negatively on the ratio of the amount of human capital to nonhuman capital in the economy $(f)$. Since we are concerned with differences among families, the exact value of $\gamma$ is not usually important because that is common to all families. Therefore, we assume that the measurement of $H$ is chosen so that $\gamma=1$.

Although human capital takes many forms, including skills and abilities, personality, appearance, reputation, and appropriate credentials, we further simplify by assuming that it is homogeneous and the same "stuff" in different families. Since much research demonstrates that investments during childhood are crucial to later development (see, e.g., Bloom 1976), we assume also that the total amount of human capital accumulated, including on-the-job training, is proportional to the amount accumulated during childhood. Then adult human capital and expected earnings are determined by endowments inherited from parents and by parental $(x)$ and public expenditures $(s)$ on his or her development:

$$
H_{t}=\psi\left(x_{t-1}, s_{t-1}, E_{\ell}\right), \quad \text { with } \quad \psi_{j}>0, \quad j=x, s, E .
$$

Ability, early learning, and other aspects of a family's cultural and genetic "infrastructure" usually raise the marginal effect of family and public expenditures on the production of human capital; that is,

$$
\frac{\partial^{2} H_{t}}{\partial j_{t-1} \partial E_{t}}=\psi_{j E}>0, j=x, s
$$

The marginal rate of return on parental expenditures $\left(r_{n}\right)$ is defined by the equation 


$$
\frac{\partial Y_{t}}{\partial x_{i-1}}=\frac{\partial H_{i}}{\partial x_{i-1}}=\psi_{x}=1+r_{m}\left(x_{t-1}, s_{t-1}, E_{i}\right)
$$

where $\partial r_{m} / \partial E>0$ by inequality (5).

Although the human capital of different persons may be close substitutes in production, each person forms a separate human-capital "market." Rates of return to him depend on the amount invested in him as well as on aggregate stocks of human capital. Marginal rates of return eventually decline as more is invested in a person because investment costs eventually rise as his forgone earnings rise. Also, benefits decline increasingly rapidly as his remaining working life shortens (see the more extended discussion in Becker [1975]).

Nonhuman capital or assets can usually be purchased and sold in relatively efficient markets. Presumably, therefore, returns on assets are less sensitive to the amount owned by any person than are returns on human capital. Little is known about the effect of abilities, other endowments, and wealth on returns from different assets, although some theory suggests a positive relation (see Ehrlich and Ben-Zion [1976]; see also the evidence in Yitzhaki [1984]). Our analysis only requires the reasonable assumption that returns on assets are much less sensitive to endowments and accumulations by any person than are returns on human capital (a similar assumption is made in Becker $[1967,1975])$. A simple special case of this assumption is that the rate of return on assets is the same to all persons.

Much of the endowed luck of children $\left(v_{t}\right)$ is revealed to parents prior to most of their investment in children. Therefore, we assume that rates of return on these investments are fully known to parents (as long as the social environment $\left[\alpha_{l}\right]$ and public expenditures $\left[s_{t-1}\right]$ are known). Parents must decide how to allocate their total "bequest" to children between human capital and assets. We assume initially that parents can borrow at the asset interest rate to finance expenditures on children and that this debt can become the obligation of children when they are adults.

Parents are assumed to maximize the welfare of children when no reduction in their own consumption or leisure is entailed. Then parents borrow whatever is necessary to maximize the net income (earnings minus debt) of their children, which requires that expenditures on the human capital of children equate the marginal rate of return to the interest rate:

$$
r_{m}=r_{i,} \text { or } \hat{x}_{i-1}=g\left(E_{l,} s_{i-1}, r_{i}\right),
$$

$$
\text { with } g_{E}>0 \text { (by eq. [6]), } g_{r}<0 \text {, and also with } g_{s}<0
$$


if public and private expenditures are substitutes. Parents can separate investments in children (an example of the separation theorem) from their own resources and altruism toward children because borrowed funds can be made the children's obligation.

The optimal investment is given in chart 12 by the intersection of the horizontal "supply curve of funds," $r$, with a negatively inclined demand curve $\left(H H\right.$ or $\left.H^{\prime} H^{\prime}\right)$. This figure clearly shows that better-endowed children accumulate more human capital; those with the endowment $E$ accumulate $O N$ units of expenditure, while those with $E^{\prime}>E$ accumulate $O N^{\prime}>O N$. Therefore, better-endowed children would have higher expected earnings because equation (3) converts human capital into expected adult earnings. The total effect of endowments on earnings, and the inequality and skewness in earnings relative to that in endowments, is raised by the positive relation between endowments and expenditures.

CHART 12.

Rates of return on parental expenditures on children.

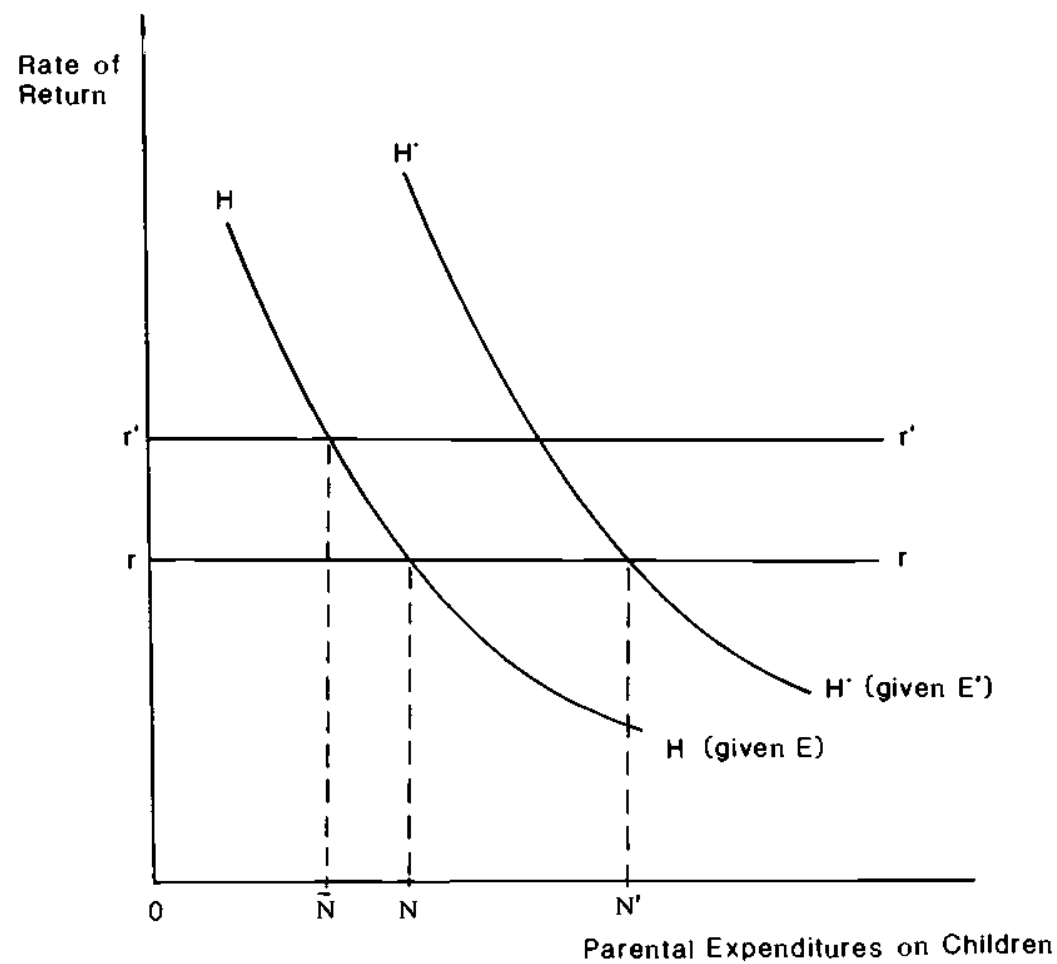


Clearly, an increase in the rate of interest reduces the investment in human capital and, hence, earnings. Compare $O N$ and $O \bar{N}$ in chart 12. The effect of an increase in public expenditures is less clear. If public expenditures are perfect substitutes dollar for dollar for private expenditures, the production of human capital would be determined by their sum $(x+s)$ and by $E$; an increase in public expenditures would then induce an equal decrease in private (parental) expenditures, and the accumulation of human capital would be unchanged. Even then, a sufficiently large increase in public expenditures would raise the accumulation of human capital because private expenditures cannot be negative.

Note that the human capital and earnings of children would not depend on their parents' assets and earnings because poor parents can borrow what is needed to finance the optimal investment in their children. However, the income of children would depend on parents because gifts and bequests of assets and debt would be sensitive to the earnings and wealth of parents. Indeed, wealthy parents would tend to self-finance the whole accumulation of human capital and to add a sizable gift of assets as well.

Although the earnings and human capital of children would not be directly related to parents' earnings and wealth, they would be indirectly related through the inheritability of endowments. The greater the degree of inheritability, the more closely related would be the human capital and earnings of parents and children. To derive the relation between the earnings of parents and children, substitute the optimal level of $x$ given by equation (7) into the earnings-generating equation (3) to get

$$
\begin{gathered}
Y_{t}=\psi\left[g\left(E_{t} s_{t-1}, r_{t}\right), s_{t-1}, E_{t}\right]+\ell_{t}=\phi\left(E_{t} s_{t-1}, r_{t}\right)+\ell_{t} \\
\text { where } \phi_{E}=\psi_{g} g_{E}+\psi_{E}=\left(\frac{\partial Y}{\partial x}\right)\left(\frac{\partial x}{\partial E}\right)+\frac{\partial Y}{\partial E}>0 .
\end{gathered}
$$

Since this equation relates $E$ to $Y, \ell, g$, and $r, E_{t}$ can be replaced by $E_{t-1}$ from (2) and then $Y_{t}$ can be related to $Y_{t-1,}, \ell_{b}, \ell_{t-1}$ and other variables:

$$
Y_{t}=F\left(Y_{t-1}, \ell_{t-1}, v_{t}, h, s_{t-1}, s_{t-2}, r_{t}, r_{t-1}, \alpha_{t}\right)+\ell_{t}
$$

Not surprisingly, the earnings of parents and children are more closely related when endowments are more inheritable $(h)$. However, the relation between their earnings also depends on the total effect of endowments on earnings $\left(\phi_{E}\right)$. If this effect is independent of the level of endowments $\left(\phi_{E E}=0\right)$, then 


$$
\begin{array}{r}
Y_{t}=c_{t}+\alpha_{t} \phi_{E}+h Y_{t-1}+\ell_{t}^{*}, \\
\text { where } \ell_{t}^{*}=\ell_{t}-h \ell_{t-1}+\phi_{E} v_{t} \\
\text { and } c_{t}=c\left(s_{t-1}, s_{t-2}, h, r_{t}, r_{t-1}\right)
\end{array}
$$

The intercept $c_{t}$ would differ among families if government expenditures $\left(s_{t-1}, s_{t-2}\right)$ differed among them. The stochastic term $\ell_{t}^{*}$ is negatively related to the market lick of parents.

If the luck of adults and children $\left(\ell^{*}\right)$ is held constant, the earnings of children would regress to the mean at the rate of $1-h$. However, the coefficient is biased downward by the "transitory" component of lifetime earnings of parents $\left(\ell_{t^{-1}}\right)$ in OLS regressions of the actual lifetime earnings of children on the actual lifetime earnings of parents $\left(Y_{t}\right.$ on $\left.Y_{t-1}\right)$. If $c_{t}$ is the same for all families, the expected value of the regression coefficient would equal

$$
b_{t, i-1}=h\left(1-\frac{\sigma_{\ell}^{2}}{\sigma_{y}^{2}}\right)
$$

where $\sigma_{\ell}^{2}$ and $\sigma_{y}^{2}$ are the variances of $\ell_{t}$ and $Y_{r}$. This coefficient is closer to the degree of inheritability when the inequality in the transitory component of lifetime earnings is a smaller fraction of the total inequality in lifetime earnings.

Families of particular races, religions, castes, or other characteristics who suffer from market discrimination earn less than do families without these characteristics. Persons with characteristics that are subject to discrimination earn less than do persons not subject to discrimination even when their parents' earnings are equal. Persons subject to discrimination would earn less-given the degree of inheritability-as long as discrimination reduces the earnings from given endowments, for discrimination then reduces the intercept in the equation that relates the earnings of parents and children $\left(c_{t}+\alpha_{i} \phi_{E}\right.$ in eq. [11]).

\section{Imperfect Access to Capital}

Access to capital markets to finance investments in children separates the transmission of earnings from the generosity and resources of parents. Economists have argued for a long time, however, that human capital is poor collateral to lenders. Children can "default" on the market debt contracted for them by working less energetically or by entering occupations with lower earnings and higher psychic income. Such 
"moral hazard" from the private nature of information about work effort and employment opportunities can greatly affect the earnings realized from human capital. Moreover, most societies are reluctant to collect debts from children that were contracted by their parents, perhaps because the minority of parents who do not care much about the welfare of their children would raise their own consumption by leaving large debts to children.

To bring out sharply the effect of imperfect access to debt contracted for children, we assume that parents must finance investments in children either by selling assets, by reducing their own consumption, by reducing the consumption by children, or by raising the labor-force activities of children. Consider parents without assets ${ }^{3}$ who would have to finance the efficient investment in human capital (say, $O N$ in chart 12) partly by reducing their own consumption because they cannot contract debt for their children. A reduction in their own consumption would raise its marginal utility relative to the marginal utility of resources invested in children. This would discourage some expenditure on children. Consequently, both the amount invested in children and parental consumption are reduced by limitations on the debt that can be left to children. Clearly, richer parents would tend to have both higher consumption and greater investments in children.

Therefore, expenditures on children by parents without assets depend not only on endowments of children and public expenditures, as in equation (7), but also on earnings of parents $\left(Y_{t-1}\right)$, their generosity toward children $(w)$, and perhaps now also on the uncertainty $\left(\varepsilon_{i-1}\right)$ about the luck of children and later descendants, as in

$$
\hat{x}_{t-1}=g^{*}\left(E_{t}, s_{t-1}, Y_{t-1}, \varepsilon_{t-1}, w\right), \quad \text { with } g_{r}^{*}>0
$$

Public and private expenditures would not be perfect substitutes if public expenditures affected rates of return on private expenditures, as when tuition is subsidized. However, if they are perfect substitutes, $g^{*}$ would depend simply on the sum of $s_{t-1}$ and $Y_{t-1}$ : an increase in public expenditures is then equivalent to an equal increase in parental earnings. The effect of children's endowments on investments is now ambiguous $\left(g_{t}^{*} \geq 0\right)$ because an increase in their endowments raises the resources of children as well as the productivity of investments in their human capital. Expenditures on children are discouraged when chil-

\footnotetext{
${ }^{3}$ Even parents who accumulate assets over their lifetime may lack assets while investing in children.
} 
dren are expected to be richer because that lowers the marginal utility to parents of additional expenditures on children.

The demand curves for expenditures in chart 13 are similar to those in chart 12 and are higher in families with better-endowed children. The cost of funds to a family is no longer constant or the same to all families. Increased expenditures on children lower the consumption by parents, which raises their subjective discount rates (the shadow cost of finds). These discount rates are smaller to parents with higher earnings or more poorly endowed children. Expenditures on children in each family are determined by the intersection of supply and demand curves. An increase in parental earnings shifts the supply curve to the right and indices greater expenditures on children (compare $S_{1}$ and $S_{1}$ in chart 13). The distribution of intersection points determines the distribution of investments and rates of return and, hence, as shown in Becker (1967, 1975), the inequality and skewness in the distribution of earnings.

By substituting equation (13) into the earnings-generating equations (3) and (4), we get

\section{CHART 13.}

Parental expenditures on children, with capital constraints.

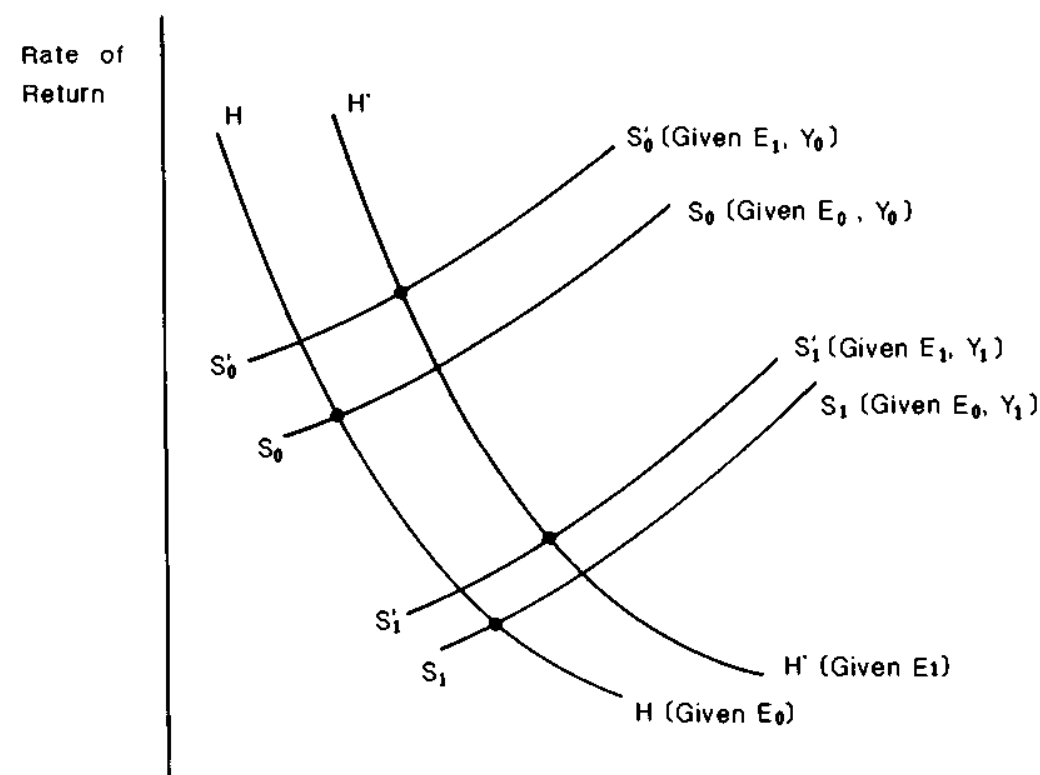

Parental Expenditures on Children 


$$
\begin{aligned}
Y_{t} & =\psi\left[g^{*}\left(E_{t}, Y_{t-1}, k_{t-1}\right), s_{t-1}, E_{t}\right]+\ell_{t} \\
& =\phi^{*}\left(E_{t}, Y_{t-1}, k_{t-1}\right)+\ell_{t}
\end{aligned}
$$

where $k_{t-1}$ includes $w, s_{t-1}$, and $\varepsilon_{t^{-1}}$. Earnings of children now depend directly on the earnings of parents as well as indirectly throngh the transmission of endowments. Some anthors (e.g., Bowles 1972; Meade 1976; Atkinson 1983) argue for a direct effect because "contacts" of parents are said to raise the opportınities of children; others argue for a direct effect because parents are said to receive utility directly from the human capital of children. Fortunately, the effects of parent earnings on access to capital can be distinguished analytically from its effects on "contacts" and "itility."

The indirect effect of parents' earnings on the earnings of children operates through the transmission of endowments and can be found by substituting $E_{t-1}$ for $E_{t}$ and then using equation (14) for $E_{t-1}$ :

$$
Y_{t}=F\left(Y_{t-1}, Y_{t-2}, \ell_{t-1}, v_{t}, h, \alpha_{t} k_{t-1}, k_{t-2}\right)+\ell_{t} .
$$

The sum of both the direct and the indirect effects of parents' earnings is

$$
\frac{\partial Y_{t}}{\partial Y_{t-1}}=\phi_{Y_{t-1}}^{*}+\frac{h \phi_{E_{t}}^{*}}{\phi_{E_{t-1}}^{*}}>0
$$

The indirect effect of grandparents' earnings, holding parents' earnings constant, is

$$
\frac{\partial Y_{t}}{\partial Y_{t-2}}=-h \phi_{Y_{t-2}}^{*}\left(\frac{\phi_{E_{t}}^{*}}{\phi_{t_{t-1}}^{*}}\right)<0
$$

Earnings of grandparents and grandchildren are indirectly linked throngh the constraints on financing investments in children. That is, the earnings of parents are not sufficient to describe the effects on children of both the resources and the endowments of parents. Equation (17) shows that an increase in the earnings of grandparents lowers the earnings of grandchildren when parents' earnings and grandchildren's luck are held constant. Constraints on financing investments in children introduce a negative relation between the earnings of grandparents and 
grandchildren and raise the positive effect of parents' earnings on children's earnings. ${ }^{4}$

If $Y_{t}$ were approximately linearly related to $E_{t}$ and $Y_{t-1}$, then ${ }^{5}$

$$
Y_{i} \equiv c^{\prime}+\left(\beta^{*}+h\right) Y_{i-1}-\beta^{*} h Y_{i-2}+\ell_{i}^{*} \text {, with } \beta^{*}=\phi_{y}^{*}
$$

The coefficient of parents' earnings exceeds the degree of inheritability by the marginal propensity to invest in the human capital of children $\left(\beta^{*}\right)$. As in equation (12). OLS estimates of the coefficient of $Y_{t-1}$ are biased downward by the transitory component of lifetime earnings. Ordinary least squares estimates of the relation between $Y_{t}$ and $Y_{t^{-1}}$ tend toward ${ }^{6}$

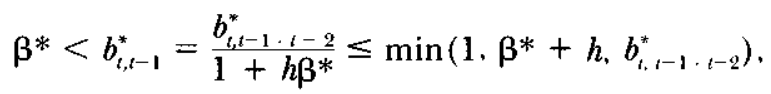

where $b_{t, t-1}^{*} \cdot t_{t-2}$ is the partial regression coefficient between $Y_{t}$ and $Y_{t-1}$. Therefore, both partial and simple regression cofficients between the lifetime earnings of parents and children provide upper limits of the effect of capital market constraints on the propensity to invest in children. The biases in these OLS estimates can sometimes be overcome by

\footnotetext{
${ }^{1}$ Goldberger (1985, pp. 16-17) perhaps properly takes us to task for expressing too much "surprise" in our earlier work about a negative coefficient on grandparents" wealth (or income) because this is implied by our model (Becker and Tomes [1979] say that a negative coefficient "may seem surprising" [p. 11711; Becker [1981] says "it is surprising" [p. 148]). However, we never claimed that an increase in grandparents' wealth would lower the wealth of grandchildren (Goldberger's discussion [1985, p. 2] is misleading about our claims). We have asked how persons who start with a presumed relation among the wealth of grandchildren, parents, and grandparents would interpret a negative coefficient on grandparents' wealth such as is found in Wahl's study (1985) reported in table 23.

${ }^{5}$ A similar equation is derived in Becker and Tomes (1979, eq. 25). However, the coefficient called $\beta$ there refers to the propensity to bequeath all capital, including debt, to children, not to the propensity to invest in the human capital of children by parents who cannot leave debt. The approximation in eq. (18) would be linear in the logs of the earnings of children, parents, and grandparents if the endowment and earnings-generating equations are linear in logs. Then $\beta^{*}+h$ would give the percentage increase in the earnings of children per $1 \%$ increase in the earnings of fathers, and similarly for $-\beta^{*} h$.
}

${ }^{5}$ Equation (18) implies that

$$
\begin{aligned}
b_{t, t-1} & \equiv \beta^{*}+h-h\left[b^{*}{ }_{\beta \beta \cdot y_{t-2}}+\epsilon_{t-1} \cdot \cdot y_{t-1}\right] \\
& \equiv \beta^{*}+h-\frac{b \sigma_{i}^{2}}{\sigma_{y}^{2}}-h \beta^{*} b_{t-1, t}^{*} .
\end{aligned}
$$

If the economy is in long-run equilibrium (see Becker and Tomes 1979), then $b_{i, t-1}^{*}=b_{t-1, t}^{*}, \sigma_{y_{t-1}}^{2}=\sigma_{y}^{2}$, and the equality in eq. (19) follows. The relation between $b_{t, t-1}^{*}$ and the right-hand side of eq. (19) is derived in Becker and Tomes (1979, app. E). 
the use of instruments for the lifetime earnings of parents, such as the lifetime earnings of uncles or of great-grandparents (see Goldberger 1979; Behrman and Taubman 1985).

The direct relation between the earnings of parents and children in equation (14) is likely to be concave rather than linear because obstacles to the self-financing investments in children decline as parents' earnings increase. When investments in the human capital of children are sufficient to lower marginal rates of return to the market rate on assets, further increases in parents' earnings raise the assets bequeathed to children but have no effect on the amount invested in the human capital of children (if rates on assets are independent of parents' earnings). Presumably, "contacts" of parents and the direct utility to parents from the human capital of children are more important in richer families. Hence, capital constraints have different implications for the curvature of the relation between the earnings of parents and children than do these alternative explanations.

Becker and Tomes's (1979) discussion implies that, because $\beta^{*}$ and $h$ enter symmetrically, even knowledge of the true values of the coefficients attached to parents' and grandparents' incomes in an equation such as (18) could not identify $\beta^{*}$ and $h$ without other information, such as which coefficient is larger. Earnings in rich families not subject to capital constraints are related by the simple equation (11), which does not include $\beta^{*}$. Therefore, $h$ would be known if the coefficient on parents' earnings in rich families is known. Then $\beta^{*}$ and $h$ could be distinguished in equation (18) by using this information on $h$.

In earlier drafts of the present paper we unwisely denote $\beta^{*}$ by $\beta$, although $\beta$ in Becker and Tomes (1979) refers to a different concept. Since the coefficient $\beta^{*}$ measures the marginal propensity to invest in the human capital of children by capital constrained parents who are prevented from making the wealth-maximizing investment in their children, $\beta^{*}$ does not enter the earnings-generating equation for richer families (eq. [11]) who are not so constrained. Put differently, $\beta^{*}$ is zero in richer families. There is no general presumption about the size of $\beta^{*}$ relative to $h$ even in low-income families because $\beta^{*}$ depends on public transfers to children, incomes, and other variables.

The coefficient $\beta$ in our earlier work (see, e.g., Becker and Tomes 1979) measures the marginal propensity to bequeath wealth to children when parents can leave debt to children and when human wealth is not distinguished from other wealth. Our earlier work and Section 3 of the present paper show that this propensity depends on the generosity of parents toward children and may not be sensitive to the level of income. However, it is likely to be large in most families (see Sec. 3). Such a 
presumption motivated the assumption in our earlier work that $\beta>h$, an assumption used to identify $\beta$ and $h$ from the coefficients in an equation such as (18).

Goldberger (1985, pp. 19-20) correctly states that we did not provide an independent way to evaluate this assumption. The present paper makes progress toward the goal of identification because $h$ can be determined from knowledge of the coefficients in the equation for the earnings of parents and children in (richer) families who leave positive bequests to children. Given $h, \beta^{*}$ (or a more general relation between $\beta^{*}$ and parents' earnings) can be determined from knowledge of the coefficients on parents' or on grandparents' earnings in the earnings equation for poorer families who are capital constrained. Even $\beta$-the marginal propensity of parents to bequeath wealth to children-might be determined from information on the relation between the consumption of parents and children in richer families (see the next section).

Rich families can more readily self-finance a given investment in children than can poor and middle-level families. Richer families also have better than average endowments, which raises the wealth-maximizing investment in human capital by richer families above that by poorer families. Empirical observations strongly indicate that richer families come closer to financing the optimal investment in the human capital of children than do poorer families. This indicates that the wealth effect on investments in children dominates the endowment effect. The wealth effect would dominate if endowments regress strongly to the mean, for then the endowments of richer children would be much below those of their parents and the endowments of poorer children would be much above those of their parents. The evidence considered in Section 6 does suggest that endowments relevant to earnings do regress strongly to the mean.

If returns on assets are not highly sensitive to earnings and endowments, the greater resources available to rich families to finance wealthmaximizing investments in children imply that equilibrium marginal rates of return on investments in children are lower in richer families than they are in more capital constrained poor and middle-level families even though endowments and average rates of return are higher in richer families. Equilibrium marginal rates then tend to decline, perhaps not monotonically, as earnings of parents rise. Eventually, marginal rates on human capital would equal the rate of return on assets, and then marginal rates would be relatively constant as parents' earnings rose. Poorer children are at a disadvantage both because they inherit lower endowments and because capital constraints on their parents limit the market value of the endowments that they do inherit. 
If marginal rates are lower in richer families, a small redistribution of human capital away from these families and toward children from poorer families would raise the average marginal rate of return across different families. This would raise efficiency even though endowments and the average productivity of investments in children are greater in richer families (see also Becker 1967, 1975). The usual conflict between "equity," as measured by inequality, and efficiency is absent because a redistribution of investments toward less advantaged children is equivalent to an improvement in the efficiency of capital markets.

Larger public expenditures on the human capital of children in families subject to capital constraints raise the total amount invested in these children even when public and private expenditures are perfect substitutes. The reason is that public expenditures increase the total resources of a family if taxes are imposed on other families. An increase in family resources in capital constrained families is shared between parents and investments in children in a ratio determined by the marginal propensity to invest $\left(\beta^{*}\right)$. If public and private expenditures are perfect substitutes, the fraction $1-\beta^{*}$ of government expenditures on children is offset by compensatory responses of their parents. That is, to further equity toward other family members, even constrained parents redistribute some time and expenditures away from children who benefit from government expenditures to siblings and themselves. Compensatory responses of parents apparently greatly weaken the effects of public health programs, food supplements to poorer pregnant women, some Head Start programs, and social security programs (see the discussion in Becker [1981, pp. 125-26, 251-53]).

We saw earlier in Section 2 that the total investment in children in families with positive bequests to children is unaffected by public expenditures on children that are perfect substitutes for parents' expenditures. Parents reduce their own expenditures to offset fully such public expenditures. However, public and private expenditures may not be perfect substitutes. If, for example, public expenditures raise rates of return on family expenditures, increased public expenditures could even raise family expenditures because a "substitution effect" works against the "redistribution effect."

Goldberger criticizes us (1985, pp. 9-10; Simon [in press] repeats Goldberger's criticism) because we emphasize redistribution or income effects at the expense of substitution effects when discussing various public programs. Since our first joint paper we have explicitly noted that government programs may have substitution effects by changing rates of return on parental investments in children (see Becker and Tomes 1976, p. S156). However, we have emphasized the redistribution effects 
of many programs-including Head Start programs, welfare, aid to pregnant women, and social security - because the redistribution effects are clear, while substitution effects are not clear, even in direction. For example, what is the substitution effect of a social security program? Or is there evidence that Head Start programs raise rather than lower marginal rates of return on parents' expenditures? (See Becker 1981, p. 126.) Although tuition subsidies to education may appear to raise rates of return on parents' expenditures on education, actually they might lower marginal rates of return when combined with rationing of places (see Peltzman 1973).

Redistributions of expenditures within families induced by government subsidies can explain why many programs appear to have weak effects on participants (see the discussion in Becker [1981, pp. 125-26, 25 1-53]). Of course, weak effects on participants do not imply that substitution effects are negligible or that they reinforce redistribution effects, but weak effects do imply that these programs do not have strong offsetting substitution effects.

Capital constrained parents could finance expenditures on children by reducing their life-cycle savings if children could be counted on to care for elderly parents. In many societies, poorer and middle-incomelevel parents are supported during old age by children instead of by the sale of gold, jewelry, rugs, land, houses, or other assets that could be accumulated by parents at younger ages. Our analysis suggests that these parents choose to rely on children instead of on assets because rates of return on investments in children are higher than they are on other assets.

In effect, poorer and middle-level parents and children often have an implicit contract, enforced imperfectly by social sanctions, that parents invest in children in return for support during old age. Both parents and children would be made better off by such contracts if investments in children yield a high return, where included in the yield is any insurance provided by children against an unusually long old age.

\section{Assets and Consumption}

Our analysis implies that bequests and gifts of assets to children do not rise rapidly until marginal rates of return on investments in children are reduced to the rate on assets. Further increases in contributions from parents then mainly take the form of assets rather than of human capital because returns on assets are less sensitive to the amount accumulated. These conclusions imply that most bequests to 
children are found in a relatively small number of richer families and that the ratio of assets to human capital of children would rise as parents' wealth rose. The empirical evidence clearly indicates that assets and income from nonhuman capital are much more important in richer than in poorer families.

Empirical studies also indicate that the proportion of income saved remains reasonably constant or that it rises as income, including "permanent" income, increases (see the studies reviewed in Mayer [1972]). However, these studies provide flawed measures of savings because investments in human capital and "capital gains or losses" from intergenerational increases or decreases in endowments are not considered savings. Lower- and middle-income families invest primarily in their children's human capital. Endowments tend to increase from parents to children at lower income levels and to decrease from parents to children at higher levels because of regression to the mean in endowments. Therefore, empirical studies understate relative savings by lower- and middle-income families because both intergenerational capital gains and investments in human capital are relatively larger in these families. We believe that an appropriate concept of savings may well show that the fraction saved declines as permanent income rises. After all, this would be expected if equilibrium marginal rates of return on investments in children decline as income increases.

Our conclusion that most bequests of assets are found in a relatively small number of richer families does not presuppose "class" differences in altruism or other class differences in the propensity to save, as in Kaldor (1956) and Pasinetti (1962), or as used in Atkinson (1983). In our analysis, all families have the same intrinsic tendency to save and leave estates because they are assumed to have the same altruism toward children. Still, apparent "class" differences in savings would exist because poorer families save mainly in the human capital of children, which are not recorded as savings or bequests.

The assets of a person are determined by bequests from parents and by his own life-cycle accumulations. We assume that parents choose bequests by maximizing their expected utility, subject to the expected earnings and life-cycle asset accumulation of children. To develop further our analysis of bequests, we must turn to an explicit treatment of utility maximization by parents. We continue to assume, until the next section, that each adult has one child without marriage.

Suppose that the utility function of parents is additively separable in their own consumption and in various characteristics of children. Most of our analysis does not depend on a specific measure of these characteristics as long as they are positively related to the total resources of chil- 
dren. However, we can simplify the relation between the consumption by parents and children by assuming that parents' utility depends on the utility of children as in

$$
U_{t}=u\left(Z_{t}\right)+\delta U_{t+1}
$$

where $Z_{t}$ is the consumption of parents and $\delta$ is a constant that measures the altruism of parents.

If the preference function given by equation (20) is the same for all generations and if consumption during childhood is ignored, then the utility of the parent indirectly would equal the discounted sum of the utilities from the consumption of all descendants:

$$
U_{t}=\sum_{i=0}^{\infty} \delta^{i} u\left(Z_{t+\mathrm{i}}\right) .
$$

The utility of parents depends directly only on the utility of children, but it depends indirectly on all descendants because children are concerned about their descendants.

We assume that parents succeed in maximizing their "dynastic" utility, as represented by equation (21). This rules out bargaining by children to obtain larger transfers than those that maximize parents' utility. A more general assumption is that parents maximize a weighted average of their own and their children's utility, with weights determined by bargaining power (see the normative use of this assumption in Nerlove, Razin, and Sadka [1984]); however, this generalization would not change any major conclusions.

With perfect certainty about rates of return and incomes in all generations, the first-order conditions to maximize utility are the usual ones. For example, with a constant elasticity of substitution in consumption,

$$
u^{\prime}(Z)=Z^{-\sigma},
$$

where $\sigma>0$, and

$$
\ln Z_{t+1}=\frac{1}{\sigma} \ln \left(1+r_{t+1}\right) \delta+\ln Z_{i},
$$

where $r_{1+1}$ measures the marginal rate of return to investments in children in period $t$. With an exponential utility function,

$$
u^{\prime}(Z)=e^{-p Z}, \quad p>0
$$

and 


$$
Z_{i+1}=\frac{1}{p} \ln \left(1+r_{i+1}\right) \delta+Z_{r}
$$

If parents could finance expenditures on their children with debt that becomes the obligation of children, the marginal cost of funds wolld equal the rate on assets in all families. Then equation (23) or equation (25) implies that the relative or absolute change in consumption between generations wonld be the same in all families that are equally altruistic $(\delta)$ and that have equal degrees of substitution $(\sigma$ or $p$ ). Each family would maintain its relative or absolute consumption position over generations, and consumption wolld not regress to the mean. Stated differently, any degree of relative or absolute inequality in consumption in the parents' generation would then be fully transmitted to the children's generation.

Nevertheless, the earnings of children wonld still regress to the mean, regardless of the altruism of parents, as long as endowments are not fully inherited by children (see Sec. 2). Consumption does not automatically regress to the mean when earnings do because parents can anticipate that their children would tend to earn less or more than they do. They can use debt and assets to offset the effect on wealth of the expected regression in earnings.

Therefore, althongh earnings may regress to the mean, well-being as measured by consumption would not regress at all if parents have full access to capital markets to finance investments in their children's human capital. The assets bequeathed to children would rise and the debt bequeathed wonld fall as parents' earnings rose. This crucial distinction between regression across generations in earnings and consumption appears to have been ignored in the extensive literature on the mobility of families.

Still, the main implication of equations such as (23) and (25) is disquieting, namely, that all initial differences among families in consumption and total resources are fully transmitted to futture descendants. Surely, the resolurces of the current generation are essentially independent of the resources of their distant ancestors. Several forces are responsible for the decay over time in the influence of the past on consimption and total resources. These include difficulties in transmitting debt to children, uncertainty about the future, the effect of parents' wealth on fertility, and imperfect assortative mating. We consider these variables in turn.

Consumption is fully separated from earnings only when children can be obligated for debts created by parents. If debt cannot be created for children (see the discussion in Sec. 2), parents withont assets conld not 
offset any npward regression in the endowments and earnings of their children. Parents wonld face a complicated maximization problem becanse capital constraints may be binding only for some descendants. The results of ntility maximization can be summarized by endogenously determined subjective discount rates and marginal rates of return for each generation of a family that guide as well as reflect the decisions for that generation. These shadow prices exceed the rate on assets whenever constraints on access to debt prevent borrowing from children. Discount rates of (richer) parents with sufficient assets to raise or lower their bequests to children would equal the rate on assets.

We argne in Section 2 that equilibrium marginal rates of return of constrained parents tend to decline as their earnings become larger. Then equation (23) or equation (25) implies that the relative or absolute growth in consumption between generations would also decline as the earnings of parents rose. However, the relative or absolute growth in consumption between generations would be constant among richer families who receive a marginal rate of return equal to the rate on assets. Therefore, the consumption of children would regress more rapidly upward to the mean in poor families than downward to the mean in rich families. This produces a convex relation between the consumption of parents and children. At the same time, earnings regress more slowly npward in poor families than they regress downward in rich families.

Assets bequeathed to children in richer families act as a buffer to offset any regression to the mean in the earnings of children. The richest families could maintain their consumption over time compared to less rich families only by increasing their bequests sufficiently to offset the stronger downward regression in the earnings of the richest children. As a result, bequests could regress away from the mean.

Our analysis of consumption has assumed perfect certainty, although uncertainty about much of the luck of future generations is not fully insurable or diversifiable. If each generation knows the yields on investments in the human capital of children and in bequests to children, but may not have perfect certainty about the earnings of children and is still more uncertain about subsequent generations, then the first-order condition for maximization of expected utility is

$$
\varepsilon_{t} u^{\prime}\left(Z_{t+1}\right)=\left(\frac{\delta^{-1}}{1+r_{t+1}}\right) u^{\prime}\left(Z_{t}\right)
$$

where $\varepsilon_{t}$ refers to expectations taken at generation $t$ before any new information about earnings and other wealth of descendants is acquired between $t$ and $t+1$. 
With the exponential function, this first-order condition becomes

$$
\mathrm{Z}_{t+1}=c+\frac{1}{p} \ln \left(1+r_{t+1}\right) \delta+Z_{t}+n_{t+1}
$$

where $c$ is a positive constant and where $n_{t+1}$, the distribution of fluctuations in $Z_{t+1}$ around $\hat{Z}_{t+1}$, does not depend on $Z_{t}$. If the capital market permitted all families to finance the wealth-maximizing investments in their children, $r_{t+1}=r_{a}$ in all families, where $r_{n}$ is the asset rate. Then equation (27) implies that the growth in consumption follows a random walk with drift (Kotlikoff, Shoven, and Spivak [1986] derive a similar result when the length of life is uncertain). More generally, equation (27) shows that, if the utility function is exponential, uncertainty adds a random term to consumption but does not basically change the implications of our analysis concerning the degree of regression to the mean in consumption.

A second-order approximation to the left-hand side of equation (26) readily shows that the effect of uncertainty on the degree of regression toward the mean with more general utility functions than the exponential depends on the signs and magnitudes of second- and higher-order derivatives of the utility function. ${ }^{7}$ Uncertainty could induce regression toward the mean in consumption even when there would be none with certainty. However, uncertainty could also induce regression away from the mean, or greater rates of regression toward the mean at higher rather than at lower levels of consumption, with utility functions that otherwise seem as empirically relevant as those having opposite implications. Consequently, we cannot make any strong statement concerning the effect of uncertainty on the degree of regression toward the mean in the consumption of parents and children.

' If $r_{t+l}$ is constant, a second-order approximation to $u_{t+1}^{\prime}$ in eq. (26) gives

$$
\frac{d \hat{Z}_{t+1}}{d Z_{t}}=\left(\frac{u_{t}^{\prime \prime}}{u_{f}^{\prime}}\right)\left[\begin{array}{l}
u_{t+1}+\frac{v u_{t+1}^{\prime \prime}}{2} \\
u_{t+1}^{\prime \prime}+\frac{v u_{t+1}^{\prime \prime \prime}}{2}
\end{array}\right]
$$

where $u_{++}^{\prime \prime \prime} 1$ is the third derivative, $u_{t+1}^{\prime \prime \prime}$ is the fourth derivative of utility from consumption in the $t+1$ first generation, and $v$ is the given variance of $n_{t+1}$ around $\hat{Z}_{t+1}$. The term on the left-hand side is more likely to be less than one (regression toward the mean) when $(u)^{\prime \prime \prime \prime}$ is large relative to $(u)^{\prime \prime \prime}$. 


\section{Fertility and Marriage}

Regression toward the mean in marriage and the positive effect of wealth on fertility help explain why differences in consumption and total resources among richer families do not persist indefinitely into future generations. Here we only sketch out an analysis. The implications of fertility and marriage for consumption and bequests are also discussed in Becker and Tomes (1984) and Becker and Barro (1985).

Let us first drop the assumption that all parents have only one child and generalize the utility function in equation (20) to

$$
U_{p}=u\left(Z_{p}\right)+a(n) n U_{r},
$$

with $a^{\prime}<0$, where $U_{c}$ is the utility of each of the $n$ identical children and $a(n)$ is the degree of altruism per child. The first-order condition for the optimal number of children is that the marginal utility and marginal cost of children are equal. The marginal cost of children to parents equals net expenditures on children, including any bequests and other gifts. The marginal costs are determined by the circumstances and decisions of parents.

The previous section showed that the consumption and total resources of wealthy families may not regress down because these families can offset the downward regression in the earnings of their children by sufficiently large gifts and bequests. Fortunately, this unrealistic implication does not hold when the number of children can vary. Richer families tend to spend some of their greater resources on additional children. This reduces the bequest to each child below what it would be if they did not increase the number of children (see the proofs in Becker and Barro [1985]). A positive response of fertility to increases in wealth causes consumption and wealth per child to regress down, perhaps rapidly.

Poor and middle-income families without assets who are prevented from leaving debt to their children must trade off between earnings of each child, number of children, and parent consumption. The human capital invested in each child and, hence, the earnings of each child would then be negatively related to the number of children, as found in many studies (see, e.g., Blake 1981). The degree of regression to the mean in earnings among these families would be lower if fertility and parents' earnings are negatively related than if they are unrelated.

We do not have much to add to our previous analysis (see Becker and 
Tomes 1976; Becker 1981, chap. 6; Tomes 1981) of responses to differences between children. This analysis implies that richer families invest more human capital in better-endowed children and that they compensate other children with larger gifts and bequests. Poorer families who primarily invest in human capital face a conflict between the efficiency of greater investments in better-endowed children and the equity of greater investments in less well endowed children.

Despite the claim that observed differences between siblings in earnings is helpful in determining the degree of intergenerational mobility in earnings (see, e.g., Brittain 1977, pp. 36-37), there is no necessary connection between the relation among siblings and the degree of intergenerational mobility. The reason is that differences in earnings between siblings is determined by characteristics within a single generation, such as the substitution between siblings in the utility function of parents, whereas intergenerational mobility in earnings is determined by differences across generations, such as the regression toward the mean of endowments (for a further discussion, see Tomes [1984]).

Regression to the mean in marriage-called imperfect positive assortative mating - also increases the degree of regression to the mean in earnings, consumption, and assets. However, the effect of marriage is less obvious than it may appear because parents often can anticipate the marital sorting of children. For example, wealthy parents would use gifts and bequests to offset some of the effects on the well-being of their children of the tendency for rich children to marry down, just as they use gifts and bequests to offset the effect of the regression downward in endowments. Although a full analysis of the interaction between the behavior of parents and expectations about the marriages of children is complicated by bargaining between in-laws on the gifts to be made to their children (some issues are discussed in Becker [1981, chap. 7] and Becker and Tomes [1984]), one cannot be satisfied with the many models that simply ignore expectations about children's marriages (see, e.g., Stiglitz 1969; Pryor 1973; Blinder 1976; Atkinson 1983).

Fertility and marriage have not been fully integrated into our analysis of intergenerational mobility-we only would insert "fully" into Goldberger's statement that "it's fair to say that [fertility and marriage are] not integrated into his intergenerational system" (1985, p. 13). However, the discussion in this section, the discussion of fertility in Becker and Barro (1985), and that of marriage in Becker and Tomes (1984) indicate to us that a utility-maximizing approach can integrate fertility, marriage, and intergenerational mobility into a common framework with useful implications. 


\section{Empirical Studies ${ }^{8}$}

Only a few empirical studies link the earnings or wealth of different generations because of difficulties in gathering such information and because of insufficient interest by social scientists. Tables 22 and 23 present estimates from several studies of the degree of regression to the mean in earnings, income, and wealth, with coefficients of determination (when available), the number of observations, and notes about other variables (if any) included in each regression.

Table 22 has evidence on the earnings or incomes of sons and fathers from three studies based on separate data sets for the United States and one study each for England, Sweden, Switzerland, and Norway. ${ }^{9} \mathrm{Al}-$ though the average age of fathers and sons is quite different except in the Geneva study, both Atkinson (1981) and Behrman and Taubman (1983) present evidence that such differences in age do not greatly affect the estimated degree of regression to the mean.

The point estimates for most of the studies indicate that a $10 \%$ increase in father's earnings (or income) raises son's earnings by less than $2 \%$. The highest point estimate is for York, England, where son's hourly earnings appear to be raised by $4.4 \%$. However, the confidence intervals are sizable in all studies except Malmö because fathers' earnings "explain" a small fraction of the variation in the earnings of sons. Moreover, response errors and the transitory component in father's earnings (or income) may severely bias these regression coefficients. ${ }^{10}$ Furthermore, the analysis in Section 2 indicates that transitory variations in lifetime earnings, and the omission of the earnings of grandparents biases these regression coefficients downward. However, the error from omitting grandparents' earnings would be small if parents' earnings do not have a large effect (see eq. [18]) and if the transitory in lifetime earnings is not large.

\footnotetext{
${ }^{4}$ We are indebted to Robert Hauser for bringing to our attention several studies of intergenerational mobility that use the data on Wisconsin high school graduates and for guiding us through various adjustments that correct for response and measurennent errors in these studies.

${ }^{9}$ These studies have various limitations. Hauser et al. (1975) sample families in only one state (Wisconsin) and only include sons who graduated from high school; all fathers in the Behrman and Tautbman (1983) sample are twins; fathers in the Atkinson (1981) sainple had modest earnings in the city of York; fathers in the de Wolff and van Slijpe (1973) study are from the city of Malmö; Soltow (1965) uses a very small sample from one city in Norway; and Girod (1984) surveys students in the canton of Geneva.

I" These estimates may also be biased (the direction is not clear) because information is not available on hours worked and nonpecuniary income from employment (see the discussion in Becker and Tomes [1984, n. 13]).
} 
Hauser et al. (1975) reduce response errors and the transitory component by using a four-year average of parents' income and a three-year average of son's earnings, while Hauser (in press) uses a four-year average of parents' income and a five-year average of son's earnings during his initial period of labor-force participation. Tsai (1983) not only averages incomes of parents over several years but also uses a retrospective report on their income in 1957. At Hauser's suggestion, we have corrected for the response errors in father's earnings by using the analysis in Bielby and Hauser (1977). Behrman and Taubman (1983) exclude sons who have less than four years of work experience because their earnings do not represent well their lifetime earnings. De Wolff and van Slijpe (1973) and Freeman (1981) reduce the importance of the transitory component by using the average income in father's occupation as an estimate of his lifetime earnings.

Despite these adjustments for response errors and transitory incomes, point estimates of the regression coefficients for earnings and incomes are rather low in all the studies (except for large incomes in Sweden). Moreover, a study in progress by Elizabeth Peters (1985) that uses data from the National Longitudinal Survey (the same survey used by Freeman [1981]) also finds a small coefficient (below .2) when a simple average of four years of son's earnings is regressed on a simple average of five years of father's earnings.

Some indirect evidence of sizable regression toward the mean in lifetime earnings is provided by life-cycle variations in earnings. By definition, endowments are fixed over a lifetime. Therefore, earnings should be more closely related over the life cycle than across generations because endowments are imperfectly transmitted from parent to child (endowments are not a "fixed effect" across generations). Stated differently, relative to other members of his cohort, a person is usually much more similar to himself at different ages than is a father similar to his son when they are of the same age. The correlation coefficient between the "permanent" component of male earnings at different ages has been estimated from a seven-year panel to be about 7 in the United States (see Lillard and Willis 1978, table 1). The inheritability of endowments from fathers to sons is surely less, probably much less, than is the correlation between the permanent component of earnings at different ages.

The evidence in table 22 suggests that neither the inheritability of endowments by sons $(h)$ nor the propensity to invest in children's human capital because of capital constraints $\left(\beta^{*}\right)$ is large. For example, if the regression coefficient between the lifetime earnings of fathers and sons is $\leq .4$ and if the transitory variance in lifetime earnings is less than one-third of the variance in total lifetime earnings, then both $h$ and $\beta^{*}$ 


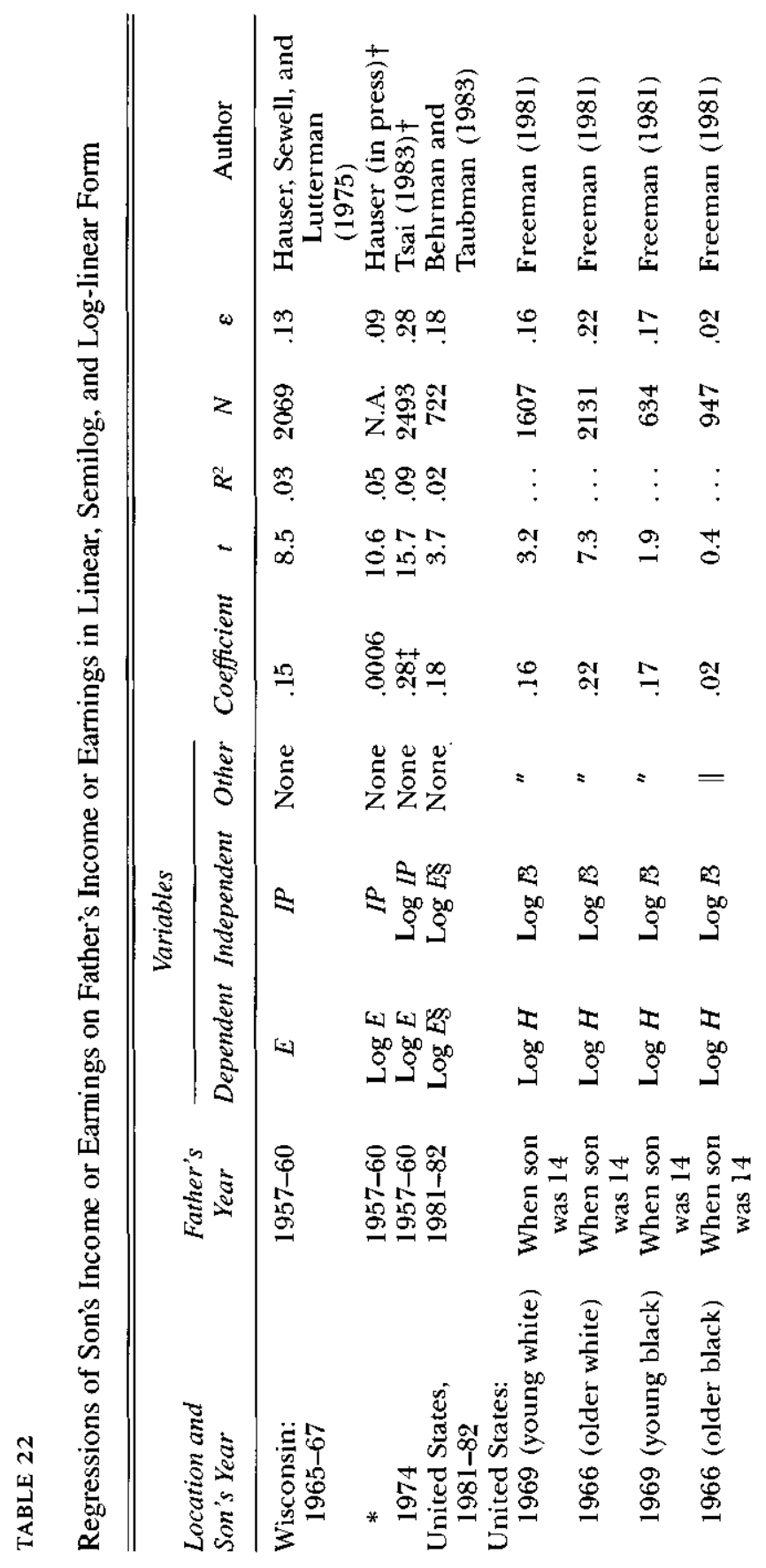




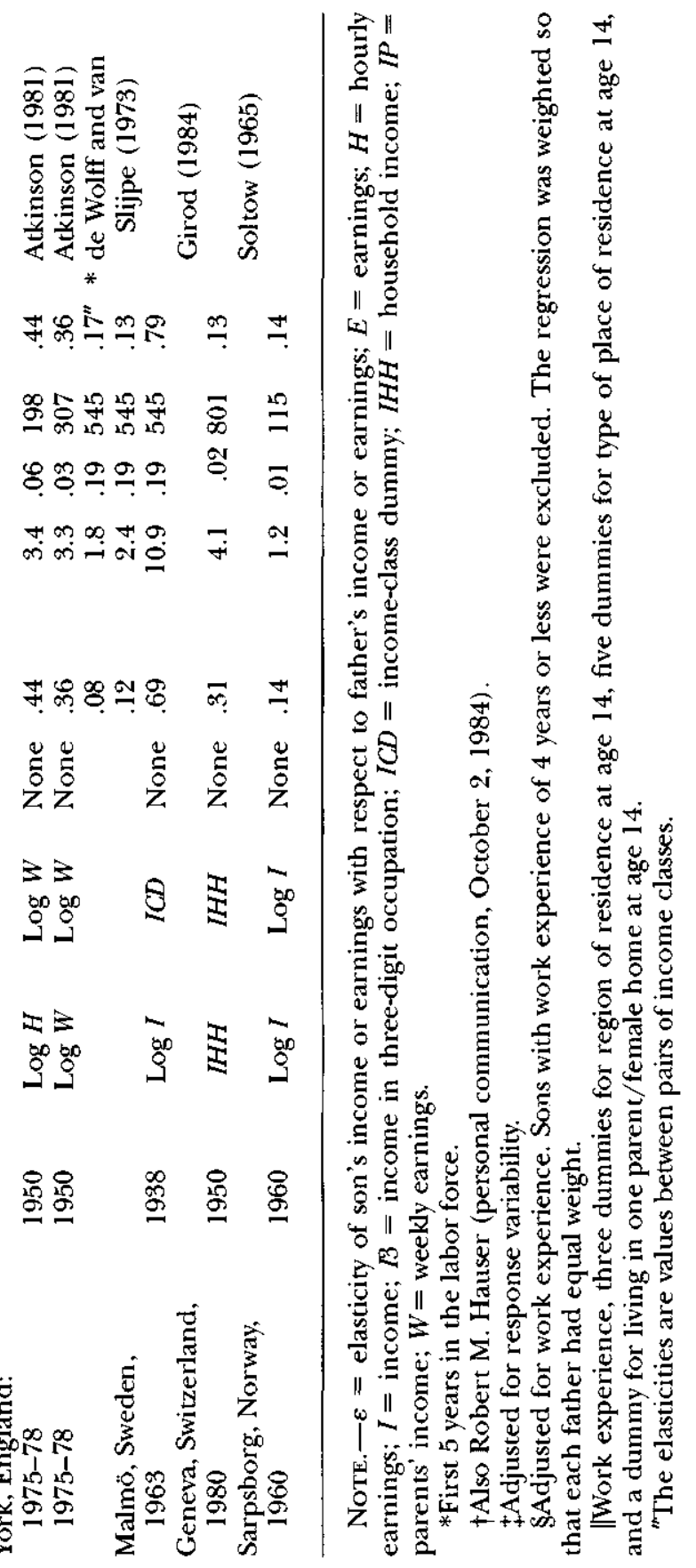


would be less than .28 if $h=\beta^{*}$; moreover, $h \leq .6$ if $\beta^{*}=0$, and $h \leq 0$ if $\beta^{*} \geq .4$ (see n. 4 ).

If capital constraints completely disappeared, would the same families dominate the best-paid and most prestigious occupations? (For this fear, see the often-cited article by Herrnstein [1971].) The answer is no: families in the best occupations would change frequently even in "meritocracies" because endowments relevant to earnings are not highly inheritable $-h$ is less than .6 and may be much less. Another way to see this is by noting that, if the relation between the lifetime earnings of fathers and sons is no larger than .4, practically all the advantages or disadvantages of ancestors tend to disappear in only three generations: "from shirtsleeves to shirtsleeves in three generations." Parents in such "open" societies have little effect on the earnings of grandchildren and later descendants. Therefore, they have little incentive to try to affect the earnings of descendants through family reputation and other means.

In particular, any lifetime "culture of poverty" tends to disappear between generations because characteristics that determine earnings are variable between generations. For example, children of parents who earn only half the mean can expect to earn above $80 \%$ of the mean in their generation, and their own children can expect to earn only slightly below the mean.

Yet, family background is still important. For example, even if the degree of regression to the mean is $80 \%$, children of parents whose earnings are twice the mean tend to earn $30 \%$ more than the children of parents whose earnings are only $50 \%$ of the mean. A $30 \%$ premium is large relative to the $10 \%-15 \%$ premium from union membership (see Lewis 1986) or to the $16 \%$ premium from two additional years of schooling (see Mincer 1974). Children from successful families do have a significant economic advantage.

Families who are poor partly because of discrimination against their race, caste, or other "permanent" characteristics may advance more slowly. Clearly, blacks in the United States have advanced much more slowly than have immigrants, partly because of public and private discrimination against blacks. Although many have studied changes over time in the average position of blacks relative to whites (see, e.g., the excellent recent study by Smith [1984]), few have studied the relation between earnings of sons and fathers in black families. The evidence in table 22 suggests that older blacks regress more rapidly to the mean than do older whites, although the evidence may be spurious because response errors are higher and apparently more complicated for blacks (see Bielby, Hauser, and Featherman 1977). Opportunities for younger blacks clearly have improved during the last 20 years. The evidence in table 22 that younger blacks regress more slowly suggests that discrimina- 
tion raises the regression toward the mean in earnings (see the theoretical discussion in Sec. 2).

Goldberger points out (1985, pp. 29-30) that our earlier work uses much higher illustrative values for $\beta$ than the values of $\beta^{*}$ suggested by the empirical evidence in this section. But $\beta$ and $\beta^{*}$ are different: to repeat, $\beta$ refers to the propensity to bequeath wealth to children by families who are not capital constrained. Therefore, low $\beta^{*}$ 's are not inconsistent with high $\beta$ 's. A low $\beta^{*}$ combined with a low $h$ does imply sizable intergenerational mobility in earnings, whereas a high $\beta$ implies low intergenerational mobility in wealth and consumption among families that bequeath wealth to their children (we ignore the distinction between the wealth and consumption of children and the wealth and consumption per child; see Secs. 3 and 4).

We readily admit (see Sec. 1) that the distinction in the present paper between earnings, wealth, and consumption as well as our attention to intergenerational capital constraints and fertility behavior have greatly clarified our thinking about intergenerational mobility. However, since a low $\beta^{*}$ is not inconsistent with a high $\beta$, we see no reason why the empirical evidence of a low $\beta^{*}$ "would occasion the tearing of [our] hair and the gnashing of [our] teeth" (Goldberger 1985, pp. 29-30). Moreover, aside from fertility and marriage, we still expect high values for $\beta$ (see Sec. 3).

Table 23 presents evidence from three studies for the United States and Great Britain on the relation between the wealth of parents and children. Harbury and Hitchens (1979) and Menchik (1979) use probates of wealthy estates, while Wahl (1985) uses data on wealth from the 1860 and 1870 censuses. The estimated elasticity between the assets of fathers and sons is about .7 in the United States for probated assets in recent years but is less both for assets of living persons in the nineteenth century and for probated assets in Britain.

Wahl finds a small negative coefficient for grandparents' wealth when instruments are used for both parents' and grandparents' wealth but a positive coefficient for grandparents' wealth when their actual wealth is used. The theoretical analysis incorporated into equation (18) does imply a small negative coefficient for grandparents' wealth when the effect of parents' wealth is not large, as is the case in her study. However, Behrman and Taubman (1985) usually find small positive (but not statistically significant) coefficients on grandparents' schooling in their study of years of schooling for three generations. Their findings may be inconsistent with our theory, although equation (18) does imply a negligible coefficient for grandfathers' schooling when the coefficient on parents' schooling is small-it is less than .25 in their study.

The data in tables 22 and 23 are too limited to determine with confi- 


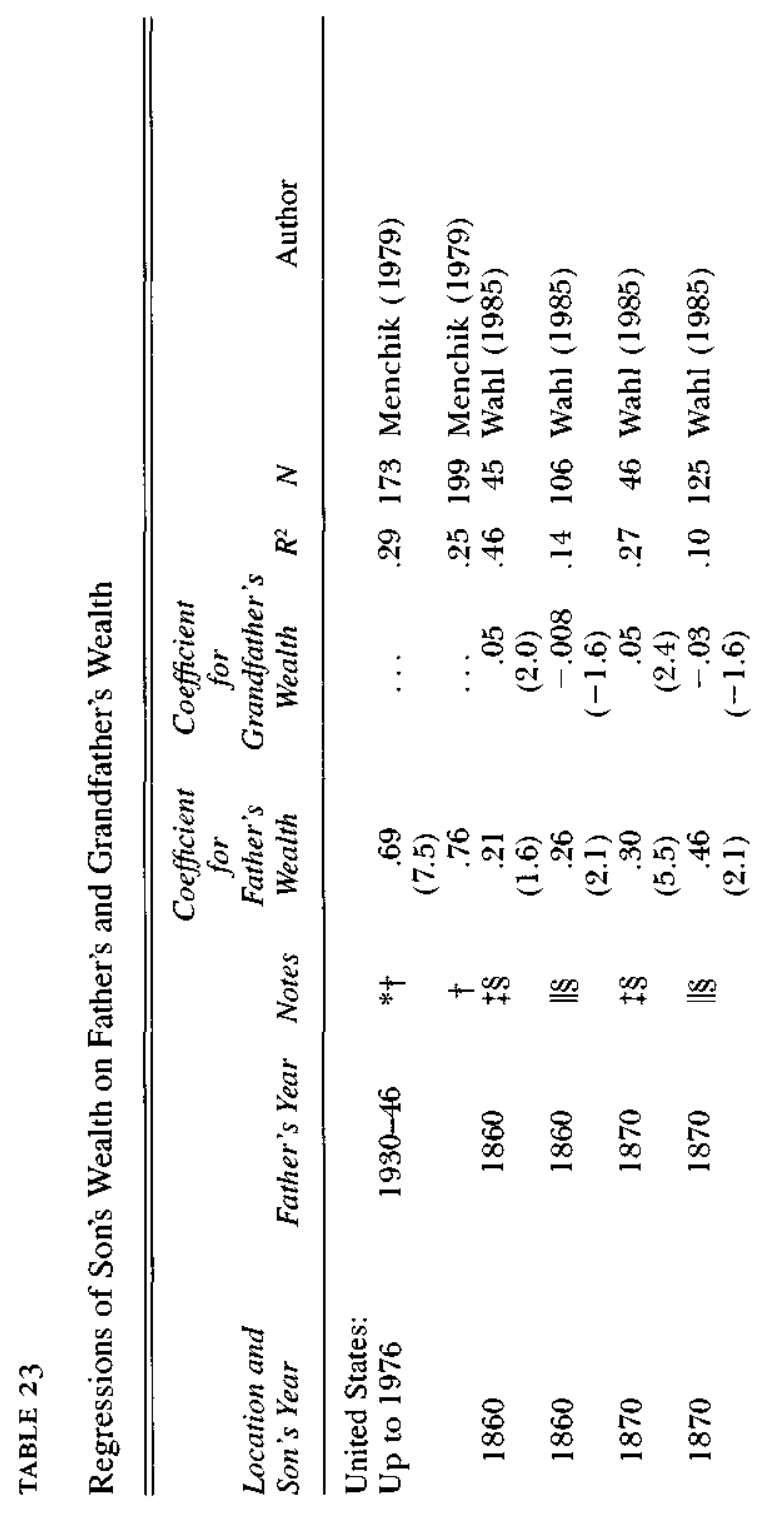




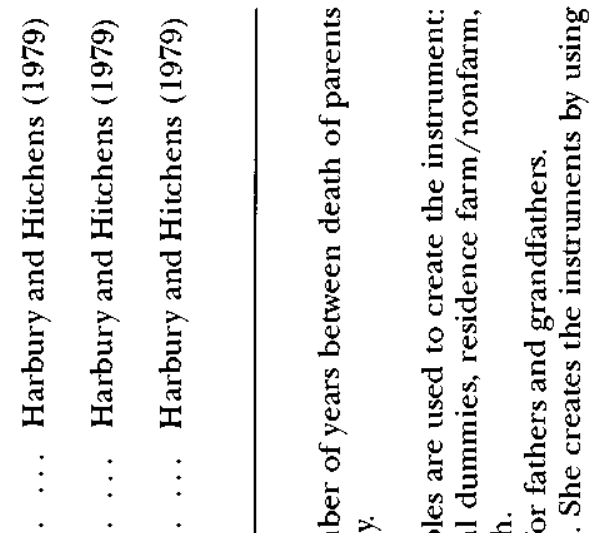

$$
\begin{aligned}
& \vdots \quad \vdots \quad \vdots \quad \text { की }
\end{aligned}
$$

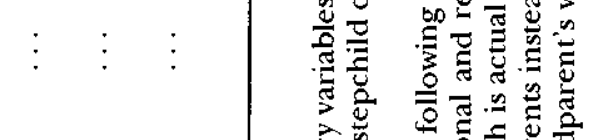

$$
\begin{aligned}
& \text { 范 }
\end{aligned}
$$

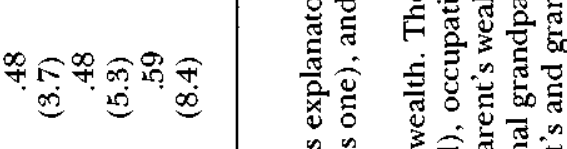

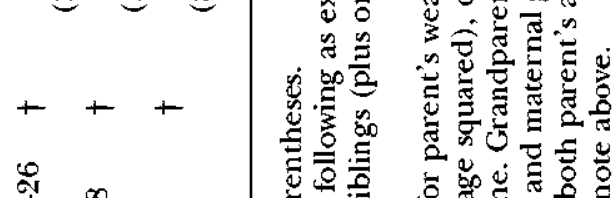

$$
\begin{aligned}
& \text { 藏 कo } \\
& \text { बั } \\
& \text { बิ ब }
\end{aligned}
$$

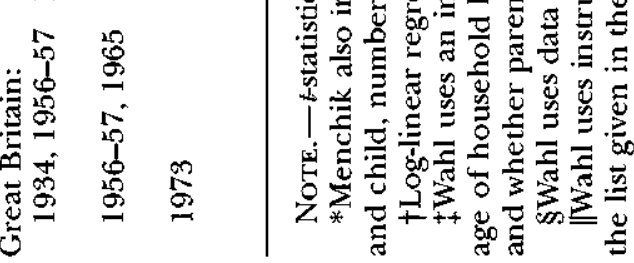


dence whether wealth or earnings regress less rapidly to the mean, although wealth appears to regress less rapidly. Wealth would regress slowly if parents bequeath assets to children to buffer the total wealth and consumption of children against regression in their earnings. However, wealth would regress rapidly if wealthier parents have sufficiently more children than do poorer parents. Wahl (1985) does find a strong positive relation in the nineteenth century between the fertility and the wealth of parents.

Capital constraints on investments in children probably declined during this century in the United States and in many other countries because fertility declined, incomes rose, and government subsidies to education and to social security grew rapidly. Evidence in Goldin and Parsons (1984) is consistent with sizable capital constraints on poor families in the United States during the latter part of the nineteenth century. These families withdrew their children from school at early ages in order to raise the contribution of teenage children to family earnings. A weakening of capital constraints in the United States is also indicated by the decline over time in the inequality in years of schooling and by the declining influence of family background on education attainments of children (Featherman and Hauser 1976).

There is evidence that the influence of family background on the achievements of children is greater in less developed countries than it is in the United States. For example, father's education has a greater effect on son's education in both Bolivia and Panama than in the United States. Moreover, the influence of father's education apparently declined over time in Panama as well as in the United States (see Kelley, Robinson, and Klein 1981, pp. 27-66; Heckman and Hotz 1985).

\section{Summary and Discussion}

This paper develops a model of the transmission of earnings, assets, and consumption from parents to children and later descendants. The model is based on utility maximization by parents concerned about the welfare of their children. The degree of intergenerational mobility, or the rise and fall of families, is determined by the interaction of utilitymaximizing behavior with investment and consumption opportunities in different generations and with different kinds of luck.

We assume that cultural and genetic endowments are automatically transmitted from parents to children, with the relation between the endowments of parents and children determined by the degree of "inheritability." The intergenerational mobility of earnings depends on the in- 
heritability of endowments. Indeed, if all parents can readily borrow to finance the optimal investments in children, the degree of intergenerational mobility in earnings essentially would equal the inheritability of endowments.

However, poor families often have difficulty financing investments in children because loans to supplement their limited resources are not readily available when human capital is the collateral. Such capital market restrictions lower investments in children from poorer families. Intergenerational mobility in earnings then depends not only on the inheritability of endowments but also on the willingness of poor families to self-finance investments in their children.

The degree of intergenerational mobility in earnings is also determined by the number of children in different families. Additional children in a family reduce the amount invested in each one when investments must be financed by the family. Consequently, a negative relation between family size and the earnings of parents also reduces the intergenerational mobility of earnings.

Assets act as a buffer to offset regression to the mean in the endowments and, hence, in the earnings of children. In particular, successful families bequeath assets to children to offset the expected downward regression in earnings.

Parents with good access to capital markets can transfer assets or debt to nullify any effect of regression to the mean in earnings on the consumption of children. This effectively separates the relation between the consumption by parents and children from inheritability of endowments and regression to the mean in earnings. Consumption in poorer and middle-level families who do not want to leave bequests tends to regress upward because equilibrium marginal rates of return on investments in the human capital of children tend to be higher in families with low earnings. Consumption and total resources in richer families that do leave bequests to children regress down to the mean, mainly because fertility is positively related to parents' wealth. In this way, larger families dilute the wealth bequeathed to each child. Imperfect assortative mating also tends to cause consumption and wealth to regress to the mean.

We have examined about a dozen empirical studies relating the earnings, income, and assets of parents and children. Aside from families victimized by discrimination, regression to the mean in earnings in the United States and other rich countries appears to be rapid, and the regression in assets is sizable. Almost all earnings advantages and disadvantages of ancestors are wiped out in three generations. Poverty would not seem to be a "culture" that persists for several generations.

Rapid regression to the mean in earnings implies that both the inher- 
itability of endowments and the capital constraints on investments in children are not large. Presumably, these constraints became less important as fertility declined over time and as incomes and subsidies to education grew over time.

In this paper and in previous work we claim that a theory of family behavior is necessary to understand inequality and the rise and fall of families. In making the claim, however, we have not intended to downgrade the importance of empirically oriented studies. Indeed, we have always viewed them as a necessary complement to theoretical analysis. We apologize if our claims for maximizing theory could be interpreted as denying the value of empirical and statistical work that is not explicitly based on a model of maximizing behavior.

We still claim, however, that our model of family behavior is useful in understanding the effect of public policies and other events on inequality and the rise and fall of families. Here we part company with Goldberger (1985), who denies whether our theory adds much to formulations not based on a model of maximizing behavior. He claims (see esp. pp. 30-33) that our theory has few implications that differ from simple regressive models of the earnings or incomes of different generations of a family. Perhaps some perspective about the validity of his claim can be acquired through a brief summary of a few implications of our analysis.

1. Earnings regress more rapidly to the mean in richer than in poorer families. Moreover, even though endowments of children and earnings of parents are positively related, a small redistribution of investment in human capital from richer to poorer families would tend to raise the overall efficiency of investments. The reason is that investments by poorer families are constrained by limited access to funds.

2. Unlike earnings, consumption would regress more rapidly to the mean in poorer than in richer families if fertility is not related to parents' wealth. Indeed, consumption then would not tend to regress at all among rich families who leave gifts and bequests to their children.

3. However, our analysis also implies that fertility is positively related to the wealth of parents. This dilutes the wealth that can be left to each child and induces a regression to the mean among rich families in the relation between consumption per child and the consumption of parents.

We do not know of any other analysis of the family that has these implications, regardless of the approach used. The implications have not been tested empirically, but Goldberger (1985) mainly questions the novelty of the implications of our analysis, not its empirical validity. Additional implications are obtained by considering the effect of public programs. 
Becker and Tomes (1979, pp. 1175-78) show that a progressive income tax could raise the long-run relative inequality in after-tax income. The standard deviation clearly falls, but average incomes also fall eventually because parents reduce their bequests to children. Goldberger's useful calculations (1985, pp. 24-25) support our analytical proof that an increase in the degree of progressivity could actually lead to an increase in after-tax inequality. His calculations suggest, however, that a couple of generations would elapse before relative inequality might even begin to increase. He overstates the delay before which inequality might begin to increase, and he understates the likelihood of an eventual net increase, by not considering the effect of greater progressivity on the contribution to inequality of the unsystematic component of the tax system (see Becker and Tomes 1979, pp. 1177-78)."

We are not concerned with inequality in this paper, but we believe that the model developed here also implies that after-tax inequality might increase when the degree of progressivity increases. Income taxes alter behavior in our analysis partly by affecting the coefficients in equations such as (11), (18), and (27). Empirical or regressive models that start with such equations or with other equations not derived from an explicit model of behavior across generations would have difficulty in analyzing the effects of income taxes on the coefficients in these equations because such models usually provide insufficient guidance to how these coefficients are determined.

This conclusion applies to other policies as well and to various changes in the environment faced by families. Indeed, the issues are not special to inequality and intergenerational mobility but apply to efforts to understand all social behavior.

To illustrate with a different public program, consider the effects of

\footnotetext{
"Alshough Goldberger admits that we only claim a possible long-run increase in inequality, he criticizes the statement that "perhaps this conflicı between initial and equilibrium effecıs explains why the large growih in redisıribution during the lası fifty years has had only modesı effecıs on afıer-tax inequality" (Becker [1981, p. 156]; a similar siaıemenı is in Becker and Tomes [1979, p. 1178]; Goldberger omits the "perhaps" in our statemen and says we "conjeciure"). He asks, "Is it Irue that over the pasi fifty years, the mean and variance of disposable income both fell? If nol, what explanation has his model [i.e., Becker-Tomes] provided?" (1985, pp. 26-27). These are sirange quesions. We were not foolish enough to contend that only the tax system affected the growth of incomes during the past 50 years nor did we try to assess how other forces affecied inequality. Since we could prove with our model that a progressive income tax need not lower inequality in the long run, and since inequality apparenıly did not decline significantly during the pası $\mathbf{5 0}$ years, we speculated about whether progressive income taxes did lower inequality over this period. Surely, that speculation could be very relevant in forcing a reassessment of the common belief that progressive taxes lower inequality. Of course, other changes during this period could have masked a negative effect of income taxes on inequality, but this has to be proven rather than simply assumed.
} 
public debt and social security on the consumption of different generations of a family. Barro (1974) uses a model of parent altruism that is similar to the model of altruism in this paper, when fertility is fixed, to question whether social security and public debt have significant effects on consumption. Parents who make positive bequests to children do not raise their consumption when they receive social security or revenue from the issue of public debt. Instead, they raise their bequests to offset the effect of these programs on the consumption of children. However, the consumption of altruistic parents who are constrained from leaving debt to children is raised by social security and public debt, and the consumption of their children is lowered (see Drazen 1978).

To avoid misunderstanding, we hasten to add that we do not claim that all public programs are netıtralized through compensatory reductions within families. This is not true for poorer families in this example or for all families when fertility can vary (see Becker and Barro 1985). Moreover, we have shown that progressive income taxes reduce the incentive to invest in children. We claim not netutrality but that our analysis of family behavior is helpful in understanding the effects of various public programs on the rise and fall of families.

Systematic empirical evidence is necessary before this and other claims can be evaluated. We close by reiterating our belief that such evidence will confirm that the analysis of family behavior within a utilitymaximizing framework provides many insights into the rise and fall of families in modern societies.

\section{References}

Atkinson, A. B. "On Intergenerational Income Mobility in Britain." Journal of Post Keynesian Economics 3, no. 2 (1981): 194-217.

- Social Justice and Public Policy. Cambridge, Mass.: MIT Press, 1983.

Barro, Robert J. "Are Government Bonds Net Wealth?" Journal of Political Economy 82, no. 6 (1974): 1096-1117.

Becker, Gary S. "Human Capital and the Personal Distribution of Income: An Analytical Approach." Woytinsky Lecture no. 1. Ann Arbor: University of Michigan, Institute of Public Administration, 1967.

—. "A Theory of Social Interactions." Journal of Political Economy 82, no. 6 (1974): 1063-93.

- Human Cpital. 2d ed. New York: Columbia University Press (for NBER), 1975.

- A Treatise on the Family. Cambridge, Mass.: Harvard University Press, 1981.

Becker, Gary S., and Barro, Robert. "A Reformulation of the Economic Theory of Fertility." Discussion Paper no. 85-1 1. Chicago: Economics Research Center, NORC, October 1985. 
Becker, Gary S., and Tomes, Nigel. "Child Endowments and the Quantity and Quality of Children." Journal of Political Economy 84, no. 4, pt. 2 (1976): S143S162.

—. "An Equilibrium Theory of the Distribution of Income and Intergenerational Mobility." Journal of Political Economy 87, no. 6 (1979): 1153-89.

- "Human Capital and the Rise and Fall of Families." Discussion Paper no. 84-10. Chicago: Economics Research Center, NORC, October 1984.

Behrman, Jere, and Taubman, Paul. "Intergenerational Transmission of Income and Wealth." American Economic Review 66, no. 2 (1976): 436-40.

- "Intergenerational Mobility in Earnings in the U.S." Mimeographed. Philadelphia: University of Pennsylvania, Center for Household and Family Economics, 1983.

- "Intergenerational Earnings and Mobility in the United States: Some Estimates and a Test of Becker's Intergenerational Endowments Model." Review of Economics and Statistics 67, no. 1 (1985): 144-51.

Bevan, D. L. "Inheritance and the Distribution of Wealth." Economica 46, no. 184 (1979): 381-402.

Bevan, D. L., and Stiglitz, J. E. "Intergenerational Transfers and Inequality." Greek Economic Review 1, no. 1 (1979): 6-26.

Bielby, William T., and Hauser, Robert M. "Response Error in Earnings Functions for Nonblack Males." Sociological Methods and Research 6, no. 2 (1977): 241-80.

Bielby, William T.; Hauser, Robert M.; and Featherman, David L. "Response Errors of Black and Nonblack Males in Models of the Intergenerational Transmission of Socioeconomic Status." American Journal of Sociology 82, no. 6 (1977): 1242-88.

Blake, Judith. "Family Size and the Quality of Children." Demography 18, no. 4 (1981): 421-42.

Blau, Peter M., and Duncan, Otis Dudley. The American Occupational Structure. New York: Wiley, 1967.

Blinder, Alan S. Toward an Economic Theory of Income Distribution. Cambridge, Mass.: MIT Press, 1974.

_. "Inequality and Mobility in the Distribution of Wealth." Kyklos 29, no. 4 (1976): 607-38.

Bloom, Benjamin S. Human Characteristics and School Learning. New York: McGraw-Hill, 1976.

Bowles, Samuel. "Schooling and Inequality from Generation to Generation." Journal of Political Economy 80, no. 3, pt. 2 (1972): S219-S251.

Brittain, John A. The Inheritance of Economic Status. Washington, D.C.: Brookings Institution, 1977.

Conlisk, John. "Can Equalization of Opportunity Reduce Social Mobility?" American Economic Review 64, no. 1 (1974): 80-90.

Dewey, John. "Galton's Statistical Methods." Publications of the American Statistical Association 1, no. 7 (1889): 331-34.

Drazen, Allan. "Government Debt, Human Capital and Bequests in a Life-Cycle Model." Journal of Political Economy 86, no. 3 (1978): 505-16. 
Ehrlich, Isaac, and Ben-Zion, Uri. "Asset Management, Allocation of Time, and Returns to Saving." Economic Inquiry 14, no. 4 (1976): 558-86.

Featherman, David L., and Hauser, Robert M. "Changes in the Socioeconomic Stratification of the Races, 1962-1973." American Journal of Sociology 82, no. 3 (1976): 621-51.

Freeman, Richard B. "Black Economic Progress after 1964: Who Has Gained and Why?" In Studies in Labor Markets, edited by Sherwin Rosen. Chicago: University of Chicago Press (for NBER), 1981.

Girod, Roger. "Intra- and Intergenerational Income Mobility: A Geneva Survey (1950-1980)." Paper presented at the meeting of the International Sociological Association Research Committee on Stratification, Budapest, September 1984.

Goldberger, Arthur S. "Family Data Analysis: Assortment, Selection, and Transmission." Proposal to the National Science Foundation, Washington, D.C., 1979.

—. "Modelling the Economic Family." Woytinsky Lecture. Ann Arbor: University of Michigan, Institute of Public Administration, 1985.

Goldin, Claudia, and Parsons, Donald O. "Industrialization, Child Labor, and Family Economic Well-Being." Mimeographed. Philadelphia: University of Pennsylvania, Department of Economics, 1984.

Harbury, C. D., and Hitchens, D. M. W. N. Inheritance and Wealth Inequality in Britain. London: Allen \& Unwin, 1979.

Hauser, Robert M. "Earnings Trajectories of Young Men." In Social Stratification in Japan and the United States, edited by D. J. Treiman and K. Tominaga. In press.

Hauser, Robert M.; Sewell, William H.; and Lutterman, Kenneth G. "Socioeconomic Background, Ability, and Achievement." In Education, Occupation and Earnings, edited by William H. Sewell and Robert M. Hauser. New York: Academic Press, 1975.

Heckman, James J., and Hotz, V. Joseph. "The Labor Market Earnings of Panamanian Males." Mimeographed. Chicago: University of Chicago, 1985.

Hermstein, Richard J. "l.Q." Atlantic 228, no. 3 (1971): 43-58.

Kaldor, Nicholas. "Alternative Theories of Distribution." Review of Economic Studies 23, no. 2 (1956): 83-100.

Kelly, Jonathan; Robinson, Robert U.; and Klein, Herbert S. "A Theory of Social Mobility, with Data on Status Attainment in a Peasant Society." In Research in Social Stratification and Mobility, vol. 1, edited by Donald J. Treiman and Robert V. Robertson. Greenwich, Conn.: JAI, 1981.

Kotlikoff, Laurence J.; Shoven, John; and Spivak, Avia. "The Effect of Annuity Insurance on Savings and Inequality." In Journal of Labor Economics 4, no. 3 (1986).

Laitner, J. P. "Househoid Bequests, Perfect Expectations, and the National Distribution of Wealth." Econometrica 47, no. 5 (1979): 1175-93.

Lewis, H. Gregg. Union Relative Wage Effects: A Survey. Chicago: University of Chicago Press, 1986.

Lillard, Lee A., and Willis, Robert J. "Dynamic Aspects of Earning Mobility." Econometrica 46, no. 5 (1978): 985-1012. 
Loury, Glenn C. "Intergenerational Transfers and the Distribution of Earnings." Econometrica 49, no. 4 (1981): 843-67.

Mandelbrot, Benoit. "Paretian Distributions and Income Maximization." Quarterly Journal of Economics 76, no. 1 (1962): 57-85.

Mayer, Thomas. Permanent Income, Wealth, and Consumption. Berkeley: University of California Press, 1972.

Meade, J. E. The Just Economy. Albany: State University of New York Press, 1976.

Menchik, Paul L. "Inter-generational Transmission of Inequality: An Empirical Study of Wealth Mobility." Economica 46, no. 184 (1979): 349-62.

Mincer, Jacob. Schooling, Experience and Earnings. New York: Columbia University Press (for NBER), 1974.

Nerlove, Marc; Razin, Assaf; and Sadka, Efraim. "Some Welfare Theoretic Implications of Endogenous Fertility." Mimeographed. Philadelphia: University of Pennsylvania, Department of Economics, 1984.

Pasinetti, Luigi L. "Rate of Profit and Income Distribution in Relation to the Rate of Economic Growth." Review of Economic Studies 29, no. 4 (1962): 267-79.

Peltzman, Sam. "The Effect of Government Subsidies-in-Kind on Private Expenditures: The Case of Higher Education." Journal of Political Economy 81, no. 1 (1973): 1-27.

Peters, Elizabeth. "Patterns of Intergenerational Mobility." Mimeographed. Boulder: University of Colorado, 1985.

Pryor, F. L. "Simulation of the Impact of Social and Economic Institutions on the Size Distribution of Income and Wealth." American Economic Review 63, no. 1 (1973): 50-72.

Roy, A. D. "The Distribution of Earnings and of Individual Output." Economic Journal 60, no. 239 (1950): 489-505.

Schumpeter, Joseph A. Imperialism and Social Classes, translated by Heinz Norden. New York: Augustus M. Kelley, 1951.

Shorrocks, A. F. "On the Structure of Inter-Generational Transfers between Families." Economica 46, no. 184 (1979): 415-25.

Simon, Herbert. "Rationality in Psychology and Economics." Journal of Business 59, no. 4, part 2 (Oct. 1986): S209-24.

Smith, James P. "Race and Human Capital." American Economic Review 74, no. 4 (1984): 685-98.

Soltow, Lee. Toward Income Equality in Norway. Madison: University of Wisconsin Press, 1965.

Stiglitz, J. E. "Distribution of Income and Wealth among Individuals." Econometrica 37 , no. 3 (1969): 382-97.

Tinbergen, Jan. "A Positive and a Normative Theory of Income Distribution." Review of Income and Wealth 16, no. 3 (1970): 221-34.

Tomes, Nigel. "The Family, Inheritance, and the Intergenerational Transmission of Inequality." Journal of Political Economy 89, no. 5 (1981): 928-58.

_- "Inequality within the Family and Regression to the Mean." Mimeographed. London: University of Western Ontario, Department of Economics, 1984 . 
Tsai, Shu-Ling. "Sex Differences in the Process of Stratification." Ph.D. dissertation, University of Wisconsin, 1983.

Wahl, Jenny Bourne. "Fertility in America: Historical Patterns and Wealth Effects on the Quantity and Quality of Children." Ph.D. dissertation, University of Chicago, 1985.

Wolff, P. de, and van Slijpe, A. R. D. "The Relation between Income, Intelligence, Education and Social Background." European Economic Review 4, no. 3 (1973): 235-64.

Yitzhaki, Shlomo. "On the Relation between Return and Income." Mimeographed. Jerusalem: Hebrew University, 1984. 